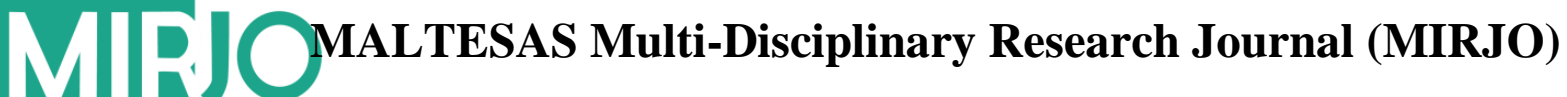

www.mirjo.maltesas.my

\section{Makna Denotatif dan Konotatif dalam Slanga Pelacur} (Denotative and Connotative Meaning in Prostitute's Slang )

\author{
Mary Fatimah Subet ${ }^{1, \text { a) }}$ dan Muhammad Zaid Daud ${ }^{1, b)}$ \\ ${ }^{1,2}$ Fakulti Bahasa dan Komunikasi, Universiti Malaysia Sarawak (UNIMAS), Jalan Datuk Mohammad Musa, 94300 \\ Kota Samarahan, Sarawak, Malaysia.

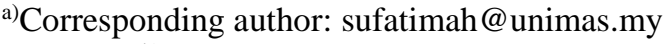 \\ b) zaid_daud93@yahoo.com
}

\begin{abstract}
Abstrak. Persepsi negatif dalam kalangan masyarakat terhadap komuniti pelacur di mana-mana di dunia ini membuatkan kajian terhadap dunia pelacuran agak terhad, misalnya kajian bahasa slanga yang dituturkan dalam kalangan mereka. Hal ini demikian kerana dunia pelacuran dianggap sebagai tabu dan tidak bermoral. Setiap perkataan yang dituturkan mempunyai makna konotatif dan memerlukan pemahaman mendalam bagi merungkai makna slanga ini. Oleh itu, kajian ini dilakukan untuk menganalisis makna dalam slanga ini. Analisis data menggunakan kaedah semantik dengan tumpuan analisis adalah terhadap makna denotasi dan konotasi sahaja. Analisis ini dapat menjelaskan makna konotatif dalam slanga ini dengan lebih jelas. Sebanyak 16 data diperolehi melalui rakaman perbualan tidak formal dengan dua orang pelacur, namun nama dan identiti mereka dirahsiakan untuk menjamin privasi mereka. Kajian mendapati, slanga yang digunakan adalah bertujuan untuk memudahkan komunikasi antara pelacur dan pelanggan mereka. Kajian juga mendapati penggunaan ujaran implisit dalam domain ini masih mampu difahami setelah makna denotasi dianalisis untuk merungkai makna konotasinya. Didapati juga, slanga dan ujaran implisit ini masih berselindung di sebalik makna eksplisitnya kerana slanga ini dianggap lucah dan kesat jika dituturkan di tempat awam. Secara keseluruhan, kajian ini dapat melakukan perincian secara lebih saintifik terhadap slanga golongan pelacur ini berbanding hanya membuat andaian umum sahaja.
\end{abstract}

Kata Kunci-slanga; pelacur; semantik; makna denotatif; makna konotatif

\begin{abstract}
Negative perception towards prostitutes globally disabling the study on prostitution goes nowhere further, for example when it comes to the usage of prostitutes' slangs. This is because the nature of prostitution itself is a taboo and an immoral doing. Every single words uttered by prostitutes depict connotative meanings and thus need in depth understanding to reveal those hidden meanings. Thus this research is carried out mainly to analyse the meanings of these slangs. Analyses are focussed mainly on the denotative and connotative meanings in the field of semantics. These analyses are able to explain clearly the connotative meanings of the slangs. 16 data were obtained from two prostitutes via informal interviews. The prostitutes chose to remain anonymous to maintain their privacy. Findings showed that slangs are used to ease communication between the prostitutes and their clients. Findings also showed that implicit utterances in this domain are understood upon revealing the connotative meanings which are hidden alongside the denotative meanings. In addition, the implicit utterances in this domain are found to be hidden despite explicit meanings are known because slangs in the prostitution domain of language are believed to be obscene and vulgar and thus considered improper to be used in public places. In conclusion, this research is able to put forward a more focussed scientific analysis of prostitutes' slangs then just merely making general assumptions only.
\end{abstract}

Keywords - slang; prostitute; semantics; denotative meaning; connotative meaning 


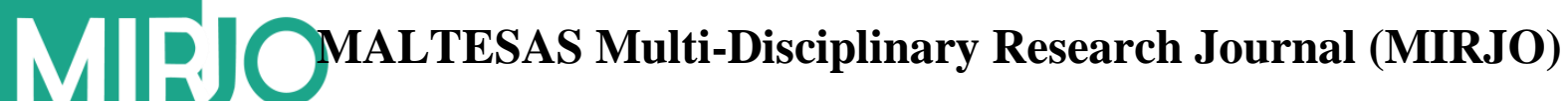

www.mirjo.maltesas.my

\section{PENGENALAN}

Kajian ini akan menganalisis slanga yang digunakan oleh pelacur dalam komunikasi lisan dengan pelanggan mereka. Kajian ini telah mengesan bahawa obsesi mencari kewangan secara mudah dengan menawarkan khidmat bersifat seksual ini telah mendorong kepada ungkapan slanga yang menjadi bahasa berlapik kepada golongan pelacur dan pelanggannya. Pelacur yang ingin menawarkan perkhidmatan mereka tidak sewenang-wenangnya menggunakan bahasa yang mudah. Golongan ini akan menggunakan bahasa-bahasa rahsia tertentu bagi mengaburi mata pihak berkuasa. Melalui ujaran berimplisit yang bersifat slanga ini telah menjadi kata kunci antara pelacur dan pelanggannya. Menurut [26], segala hajat, hasrat dan permintaan tidak dinyatakan dengan cara berterus terang, namun diungkapkan secara berkias dan berlapik agar kelihatan lebih sopan melalui kiasan ini. Begitu juga dalam konteks dan situasi golongan pelacur ini, yang tidak menggunakan bahasa yang mudah untuk mendapatkan pelanggan. Oleh itu, fokus utama kajian ini adalah berkaitan dengan slanga yang dituturkan oleh golongan pelacur ini dengan mengambil kira kebermaknaan analisis makna denotatif dan konotatif dalam bidang semantik. Dalam kajian ini, pengkaji melihat slanga bertujuan untuk menunjukkan bahawa seseorang itu terdiri daripada satu aliran atau golongan kelas sosial yang sama dan untuk merahsiakan sesuatu agar orang lain tidak memahaminya. Keduadua ciri ini jelas menunjukkan tujuan slanga yang digunakan oleh golongan pelacur terhadap pelanggan mereka. Hal ini disebabkan oleh, sesuatu kata-kata itu tidak mudah dilafazkan kepada seseorang dengan mudah bertujuan untuk menjaga peribadi seseorang pelacur itu daripada ditipu oleh pelanggannya. Kata-kata mereka bukan sekadar katakata yang dituturkan oleh mereka, tetapi mempunyai makna tersirat yang berselindung di sebalik ujaran slanga ini.

\section{SOROTAN KAJIAN LEPAS}

Kajian lepas mengenai slanga telah banyak dijalankan sama ada di dalam mahupun di luar negara daripada pelbagai perspektif kajian linguistik, antaranya dari sudut pragmatik, semantik, sosiolinguistik, morfologi, sintaksis dan sebagainya. Antara sarjana yang menjadikan slanga sebagai data kajian mereka adalah Arua \& Modupe [3], Sara Hashemi Shahraki \& Abbass Eslami Rasekh [29], Tay [30], Zhou \& Fan [32], Nadiah Suboh [22], Ahmad Ismail \& Diana Dirani [2], Kheren Kazia Adolof [13], Aboh [1], Setiawan Nugroho [28], Mary Fatimah Subet \& Muhammad Zaid Daud [16] [17]serta Muhammad Zaid Daud [21]. Dengan itu, kajian-kajian tersebut telah menjadi panduan kepada pengkaji dalam menyorot isu-isu berkaitan dengan slanga yang telah menjadi fokus kajian ini.

Sebagai contoh, Aboh [1] telah mengkaji bahasa penulisan yang digunakan oleh penulis novel di Nigeria. Penulis-penulis novel di Nigeria menggunakan slanga untuk mengekspresikan perasaan terbuka mereka mengenai seks dan tajuk yang berkaitan dengannya. [1] telah merungkai makna konotatif di sebalik penggunaan slanga dalam novel-novel berkenaan. Selain itu, Mary Fatimah Subet [15] dalam kajian beliau terhadap kehidupan pelacur, menganalisis sajak "Pelacur Tua" karya Usman Awang dan mendapati kewujudan bahasa figuratif dalam sajak seperti personifikasi, ironi dan hiperbola yang dapat menggerakkan daya imaginatif pembaca supaya turut memikirkan rasa hati pelacur yang tidak selesa, tidak bahagia, sunyi, berhati kosong, tidak sihat, menjalani kehidupan yang hancur, tiada masa depan, tidak tenang, penat, lesu, lemah, tidak bermaya, terluka, berpura-pura, kesal, sedih, kecewa, dan derita. Kajian Ahmad Ismail \& Diana Dirani [2] pula, membincangkan penggunaan istilah bagi golongan homoseksual iaitu "Orang Macam Kita" yang merupakan terjemahan secara langsung istilah People Like Us (atau singkatannya lebih dikenali sebagai PLU). Perkataan PLU ini merupakan istilah atau slanga yang sering digunakan oleh golongan homoseksual terutamanya di Malaysia dan Singapura. Di dalam penulisan ini juga, telah diterangkan bahawa ketiadaan istilah yang serupa di dalam bahasa Melayu menyebabkan mereka menterjemahkan secara langsung istilah People Like Us daripada bahasa Inggeris kepada bahasa Melayu bagi mewujudkan satu istilah baharu yang dapat digunakan oleh golongan homoseksual di Malaysia sebagai alternatif kepada istilah lain seperti gay, gay boy, lesbian, LGBT mahupun PLU itu sendiri.

Bagi sarjana dari Indonesia iaitu Kheren Kazia Adolof [13] yang di dalam tesis beliau bertajuk Slang dalam Lagu Black Eyed Peas pula, telah memfokuskan tujuan kajiannya untuk mengenal pasti slanga yang terdapat dalam lirik lagu Black Eyed Peas serta menganalisis bentuk-bentuk dan makna slanga yang terdapat dalam lagu-lagu tersebut melalui pendekatan teori Bloomfield [4] yang telah membezakan slanga kepada empat (4) jenis iaitu akronim, satu ujaran jenaka, singkatan dan interjeksi (satu kata yang mengungkapkan perasaan dan maksud 


\section{VIPATESAS Multi-Disciplinary Research Journal (MIRJO)

www.mirjo.maltesas.my

seseorang contohnya, arhh dan aduh menerangkan rasa/perasaan sakit seseorang). Antara contoh slanga ujaran jenaka, didapati sebanyak 13 data diperolehi beliau, antaranya perkataan "lil" yang membawa maksud little dalam bahasa Inggeris atau kecil dalam bahasa Melayu. Namun, dari segi perspektif slanga, kajian ini mendapati makna konotatif daripada perkataan "lil" dalam lagu tersebut dianggap sebagai jenaka berbaur lucah kerana perkataan "lil" itu membawa makna ukuran bagi alat sulit lelaki. Dengan itu, dapat disimpulkan bahawa kajian [13] ini telah memenuhi jenis-jenis slanga yang dikemukakan oleh [4] pada tahun 1933. Walau bagaimanapun, pengkaji mendapati bahawa kajian-kajian lepas tentang penggunaan data slanga pelacur sebagai fokus kajian adalah terhad. Oleh sebab itu, kajian ini menambah kekurangan bilangan kajian tentang bahasa pelacur ini. Pengkaji menyingkap makna denotasi dan konotasi dalam ujaran sebenar pelacur, bukan slanga yang diperoleh daripada novel, sajak atau lagu seperti contoh-contoh kajian yang dikemukakan di atas.

\section{METODOLOGI KAJIAN}

Data slanga dalam domain pelacur ini dikutip daripada kajian lapangan, menerusi kaedah temu bual, rakaman informan secara tidak formal serta catatan transkripsi perbualan. Prosedur menganalisis data bagi kajian ini dijalankan secara tiga peringkat seperti yang ditunjukkan dalam RAJAH 1 tersebut.

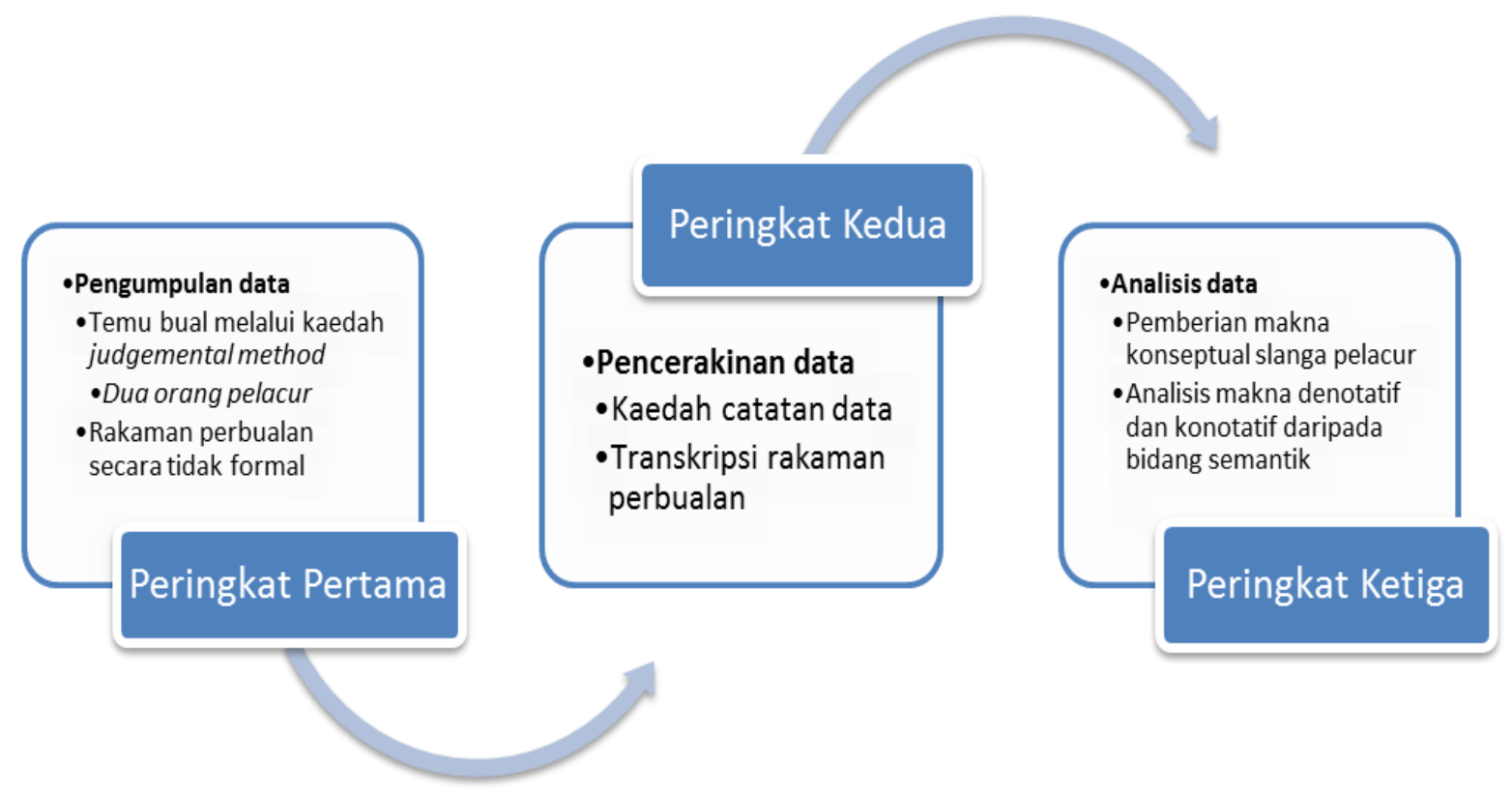

RAJAH 1. Prosedur menganalisis data

Peringkat pertama kajian ini dimulakan dengan pengumpulan data dengan menemu bual dua orang pelacur melalui kaedah judgemental method. Kaedah ini digunakan supaya pengkaji dapat menemu bual pelacur tentang perkara-perkara yang berkisar tentang pengalaman, topik-topik umum, kehidupan, dan cara melanggan yang mampu menarik perhatian mereka untuk berbual. Temu bual dimulakan dengan pengkaji menemu bual informan di lapangan kajian untuk mendekati dan cuba mengenali informan dengan lebih rapat. Pengkaji telah mendapat kerjasama yang baik daripada informan berkenaan dan menyatakan hasrat untuk mendapat data bagi tujuan penyelidikan. Informan memberi kerjasama dan boleh bertutur secara biasa dengan pengkaji. Namun, informan menyatakan syarat agar identiti mereka dirahsiakan untuk menjamin hak privasi mereka. Satu rakaman perbualan secara tidak formal telah dilakukan sepanjang perbualan dengan informan tersebut menggunakan alat rakaman audio mudah alih jenis 'ASUS' 


\section{MIRJ OMALIESAS Multi-Disipininary Reserech Journal (MIIJJ)

\section{www.mirjo.maltesas.my}

bagi tujuan merakam perbualan informan. Kaedah rakaman perbualan secara tidak langsung ini juga pernah dijalankan oleh kajian lepas mereka seperti kajian Gan [8] dan Muhammad Zaid Daud [21].

Kawasan kajian yang terlibat ialah di sekitar Bukit Bintang, Kuala Lumpur. Pemilihan kawasan kajian adalah melalui pembacaan pengkaji melalui sumber internet tentang di mana lubuk pelacuran di sekitar Kuala Lumpur dijalankan. Oleh yang demikian, pemilihan kawasan kajian ini mampu membantu pengkaji mengumpulkan data mengenai slanga pelacur. Menurut [31] lokasi kajian perlulah sesuai, mudah ditujui dan dekat dengan tempat tinggal penyelidik kerana prasyarat ini penting bagi memudahkan penyelidik menjalankan kajian bermula dengan proses memasuki lapangan kajian pada hari kejadian. Oleh itu, semasa di tempat kajian, pengkaji telah mendekati dua orang pelacur yang akan dirahsiakan nama dan bangsanya bagi tujuan menghormati dan menjaga privasi mereka. Keduadua pelacur tersebut adalah wanita, berusia 28 tahun bagi informan pertama dan 32 tahun bagi informan kedua, serta kedua-dua mereka boleh bertutur dalam bahasa Melayu dan mampu mewakili bentuk pertuturan atau bahasa yang dikehendaki oleh pengkaji.

Seterusnya, pada peringkat kedua, pengkaji mengelaskan sebagai peringkat pencerakinan data kerana selepas sahaja pengkaji memperoleh rakaman perbualan secara tidak formal di lapangan kajian tersebut, satu kaedah catatan data telah dijalankan oleh pengkaji. Hal ini bertujuan untuk memudahkan rujukan data yang diperoleh dan kemudiannya membantu pengkaji menentukan dan menilai data yang dikehendaki berdasarkan pensampelan bertujuan iaitu dengan hanya mengambil ujaran-ujaran slanga pelacur berdasarkan transkripsi perbualan antara pengkaji dengan dua orang pelacur tersebut. Audio rakaman tersebut berdurasi selama 46 minit 12 saat dan telah ditranskripsikan oleh pengkaji kepada tulisan roman.

Pada peringkat ketiga pula merupakan proses menganalisis datadan memanfaatkan kaedah semantik. Dengan tumpuan analisis diberikan terhadap makna konotasi dalam ujaran pelacur, analisis ini dapat menjelaskan makna konotatif dalam slanga domain bahasa pelacur dengan lebih jelas. Bagi proses ini, pengkaji mengelaskan dahulu makna konseptual slanga pelacur yang terdiri daripada kata tunggal/frasa, kemudian memberikan makna sebenar slanga tersebut secara eksplisit dan seterusnya secara implisit. Pada peringkat terakhir kajian ini, barulah pengkaji memanfaatkan kaedah semantik dengan mengambil kira makna denotasi dan konotasi slanga tersebut.

\section{DAPATAN KAJIAN}

Sebelum kajian ini membawa kepada kupasan makna yang lebih mendalam, pengkaji terlebih dahulu menyenaraikan sebanyak 16 ujaran slanga pelacur yang telah diperoleh daripada dua orang pelacur di sekitar Bukit Bintang, Kuala Lumpur berserta dengan makna konseptualnya. Slanga pelacur ini berbentuk istilah, perkataan, ungkapan dan juga ayat. Berikut merupakan dapatan yang diperoleh pengkaji.

JADUAL 1. Makna konseptual slanga pelacur

\begin{tabular}{ccll}
\hline Bil. & Kata Tunggal/Frasa & \multicolumn{1}{c}{ Makna Sebenar } & \multicolumn{1}{c}{ Makna Slanga } \\
\hline 1. & Bertahan & Menunggu sesuatu & $\begin{array}{l}\text { Kekuatan lelaki tersebut dalam } \\
\text { melakukan hubungan berkenaan }\end{array}$ \\
\hline 2. & Kerja & Tugasan yang perlu dilaksanakan & Melacur \\
\hline 3. & Romen & Perasaan cinta secara non-verbal & Melakukan hubungan seks \\
\hline 4. & Servis & $\begin{array}{l}\text { Memperbaiki sesuatu benda } \\
\text { ataupun barang }\end{array}$ & $\begin{array}{l}\text { Pakej yang disyorkan kepada } \\
\text { pelanggan yang melanggan pelacur }\end{array}$ \\
\hline 5. & Gundik & Pelayan raja & Perempuan simpanan \\
\hline 6. & Keyword & Kata kunci & Sebut harga pelacur \\
\hline 7. & Mangli & *istilah pelacuran & Biasa \\
\hline 8. & Tabik & Hormat & $\begin{array}{l}\text { Pelanggan yang sering mendapatkan } \\
\text { perkhidmatan pelacur }\end{array}$ \\
\hline 9. & Sales & Jualan & Keuntungan \\
\hline
\end{tabular}




\section{MIR.JOMALIESAS Multi-Disipininary Research Journal (MIIJJ) MALTESAS \\ MULTI-DISCIPUINARY RESEARCH IOURNAL}

\begin{tabular}{|c|c|c|c|}
\hline \multicolumn{4}{|c|}{ www.mirjo.maltesas.my } \\
\hline 10. & Nok & *istilah pelacuran & $\begin{array}{l}\text { Panggilan nama dalam kalangan } \\
\text { pelacur }\end{array}$ \\
\hline 11. & Pacat & Haiwan menghisap darah & Alat sulit lelaki \\
\hline \multirow[t]{3}{*}{12.} & & & $\begin{array}{l}\text { Ajakan untuk masuk ke hotel terlebih } \\
\text { dahulu sebelum membuat rundingan }\end{array}$ \\
\hline & Panjat hotel & Memanjat hotel & dan tawar menawar untuk \\
\hline & & & $\begin{array}{l}\text { mendapatkan perkhidmatan pelacur } \\
\text { tersebut. }\end{array}$ \\
\hline 13. & Sekerat jalan & Separuh jalan & $\begin{array}{l}\text { Tidak melakukan hubungan sehingga } \\
\text { selesai. }\end{array}$ \\
\hline 14. & China doll & Patung cina & Pelacur dari negara China \\
\hline 15. & Monggel-monggel & Kecil molek & Pelacur yang muda \\
\hline 16. & Siram/tanam bunga & Menanam/menyiram bunga & $\begin{array}{l}\text { Bermanja-manja dan memuji-muji } \\
\text { pelacur oleh pelanggan }\end{array}$ \\
\hline
\end{tabular}

\section{ANALISIS DAN PERBINCANGAN}

Dalam bidang semantik, makna konotatif atau konotasi secara umumnya merujuk kepada makna yang dikemukakan secara tersirat dalam sesebuah ujaran. Makna konotatif juga dilihat sebagai mempunyai kaitan dengan budaya, konteks penggunaan, pengalaman serta persekitaran, emosi, pendidikan dan pandangan tentang dunia. Menurut [25], konotasi ialah makna yang tidak berkait dengan deria, rujukan dan denotasi tetapi mempunyai faktor tambahan seperti emosi, tahap keformalan dan adakalanya bersifat eufemisme. Seterusnya, [25] mengemukakan contoh-contoh pasangan yang menurut beliau mempunyai konotasi yang berbeza tetapi denotasi yang sama iaitu bilik air/jamban, pengawal keselamatan/jaga, warga emas/warga pencen, dan ibu tunggal/janda. Beliau mengemukakan huraian yang ringkas terhadap padanan perkataan-perkataan berkenaan. Misalnya, bilik air dan jamban mempunyai rujukan yang sama tetapi penggunaan bilik air menunjukkan aspek kesopanan. Sementara, pengawal keselamatan dan jaga, menurut beliau kedua-duanya mempunyai skop tugas yang sama, tetapi penggunaan pengawal keselamatan menggambarkan kepekaan seseorang yang tidak memandang rendah terhadap pekerjaan orang lain.

Dalam kajian ini, kombinasi ujaran yang dituturkan pelacur dikaitkan dengan maklumat dalam konteks dunia pelacuran, seperti persekitaran. Gabungan ujaran dan konteks pelacuran didapati menjelaskan lagi makna di sebalik ujaran, objek dan imej berbentuk kiasan slanga yang dipilih dalam slanga pelacuran ini. 16 data slanga dalam domain pelacuran ini dikumpul daripada temu bual secara rawak dengan dua orang pelacur jalanan yang telah dirahsiakan nama, umur dan tempat mereka menjalankan perkhidmatan pelacuran ini. Kerahsiaan ini adalah untuk menjamin hak privasi mereka. Kajian ini mendapati dalam dunia pelacuran, terdapat beberapa perkataan biasa yang telah diubah suai atau diluaskan maksudnya supaya hanya mereka yang terdiri daripada golongan pelacur dan pelanggan pelacur sahaja yang memahami maknanya.

Walau bagaimanapun, bagi masyarakat biasa yang tidak mempunyai apa-apa kaitan dengan dunia pelacuran, maksudnya adalah berbeza, tidak sampai, atau sukar untuk difahami. Pemilihan perkataan juga adalah secara rawak berdasarkan ungkapan dan tutur kata yang diceritakan oleh dua orang pelacur tersebut ketika kutipan data dilakukan. Slanga yang mereka tuturkan, jika didengar pertama kali adalah bersifat lucah, namun hal ini tidak menghalang pengkaji untuk mengemukakan makna-makna yang lebih bersifat saintifik daripada hanya membuat pandangan dan pemahaman makna secara umum sahaja.

Kata-kata yang diujarkan oleh informan yang merupakan pelacur juga mempunyai tahap kehalusannya (bagi mereka), walaupun pada pendengaran umum kata-kata mereka itu sebenarnya kasar dan kesat. Jadi, seolah-olah ujaran mereka halus pada mereka, namun kasar dan kesat pada pendengaran orang yang hidup beretika dan 


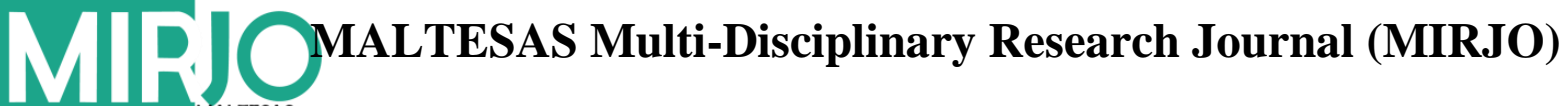

www.mirjo.maltesas.my

bermoral. Ini bermakna, mereka menganggap, mereka tidak melakukan maksiat seperti meperdagangkan tubuh badan untuk meneruskan kehidupan, sedangkan mereka mempunyai pilihan untuk hidup dengan baik berlandaskan ajaran agama yang murni. Kajian ini mendapati walaupun kata-kata mereka memang kasar dan kesat pada pendengaran umum, namun di sebaliknya, terselit makna "untuk berahsia" tentang perbuatan mereka yang tidak bermoral itu. Maksudya, mereka juga mempunyai bahasa halus mereka sendiri, sama seperti bahasa eufemisme, iaitu bahasa yang lebih halus dan manis untuk menggantikan perkataan asal yang dianggap kasar dan kesat. Misalnya, eufemisme yang digunakan sebagai pemanis bahasa untuk menjaga hati dan perasaan seseorang yang mendengar/teman bicara dalam masyarakat Melayu seperti buang air besar (berak), buang angin (kentut), panjang tangan (pencuri), anak itik (anak angkat), bulan kesiangan (anak dara tua), tempat keras (ada puaka/penunggu), anak gajah (terlalu gemuk) dan sebagainya. Kajian ini mengemukakan contoh-contoh ujaran mereka ini seperti panjat hotel/masuk ke hotel, servis/perkhidmatan seks, anu/alat kelamin, geli-geli/melakukan hubungan dan sebagainya. Contoh-contoh ujaran/frasa ini akan dibincangkan selanjutnya dalam bahagian analisis dan perbincangan di bawah.

Berikut dikemukakan 16 data berkenaan dalam bentuk perkataan dan ayat-ayat yang mereka kemukakan untuk memberi kefahaman makna kepada pengkaji, dan seterusnya pengkaji telah menghalusi makna slanga mereka ini dengan aplikasi semantik dengan memfokuskan kepada makna konotatif slanga berdasarkan konteks serta pemikiran pelacur dan pelanggan mereka. Jumlah data ialah 25 namun telah ditapis kerana ada antaranya terlalu lucah dan kesat, serta tidak sesuai untuk pembacaan umum. Maka, 16 data sahaja yang sesuai dianalisis didapati data-data berkenaan kurang lucah dan kesat. Di samping itu, jumlah dapatan data bergantung pada kekayaan dan ke perincian data untuk tujuan analisis bagi sesebuah kajian itu [31].

\section{ANALISIS DATA BERDASARKAN KATA TUNGGAL/FRASA SLANGA PELACUR}

\section{(*UJARAN BERGARIS DAN TEBAL IALAH SLANGA)}

\section{Bertahan}

Terdapat dua ujaran yang telah dikenal pasti melalui percakapan pelacur tersebut seperti mana yang terdapat pada ayat di bawah.

Ujaran pelacur:

a. "berapa lama abang punya boleh bertahan".

b. "Bertahanlah lama sikit bang ...".

Makna denotatif bagi leksikal bertahan adalah 1 tidak berganjak dr tempatnya; tidak berundur: Sekarang tentera Parsi di dalam kubunya saja, tidak mahu keluar. 2 diri menjaga diri drpd serangan musuh [11]. Walau bagaimanapun, dalam ayat di atas, ungkapan perkataan bertahan merujuk kepada ketahanan lelaki tersebut dalam melakukan hubungan seksual. Kajian mendapati perkataan ini tidak mempunyai makna tersirat sebaliknya mempunyai makna yang bermanifestasi, iaitu boleh terus difahami tanpa makna tersirat.Dalam bidang semantik, makna ini dianggap sebagai makna denotatif yang boleh diperoleh daripada kamus.Ataupun, penutur dan pendengar sendiri sudah sedia maklum akan maknanya atau menurut [25], denotasi itu sebagai kesemua kelas kata bagi sesuatu objek, benda, orang, tempat dan lain-lain yang menjadi rujukan sesuatu ungkapan. Kajian ini mengemukakan contoh ayat ini "Dia telah lama berperang dengan penyakit kanser itu. Selama ini, dia mampu bertahan sehingga menghembuskan nafasnya yang terakhir pada awal subuh tadi". "berperang" dan "bertahan" mempunyai makna denotasinya yang tersendiri dalam ayat ini. Begitu jugalah kata "bertahan" dalam ujaran pelacur ini, "berapa lama abang punya boleh bertahan" dan "Bertahanlah lama sikit bang ...", yang digunakan oleh pelacur untuk bertanyakan akan ketahanan dan kekuatan tenaga yang ada pada pelanggan tersebut. 


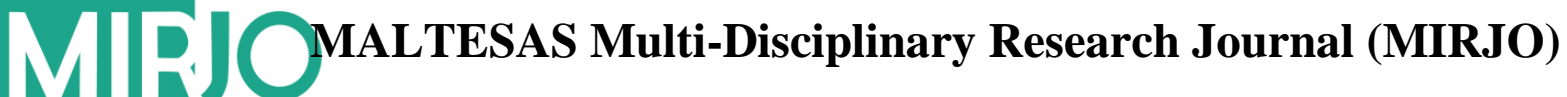

www.mirjo.maltesas.my

\section{Kerja}

Contoh ayat :

"Saya sudah kerja ini lima tahun".

Dalam pengertian umum, kerja merupakan pekerjaan, perbuatan melakukan sesuatu untuk mencapai motif-motif tertentu, boleh kerja yang negatif dan positif, halal dan tidak halal. Contoh, "Pak cik dah lama lakukan kerja ini. Pagi-pagi lagi pak cik dah menjaja nasi lemak keliling kampung" atau "Saya dah lama lakukan kerja ini, dan sekarang saya menyesal. Saya tidak mahu meragut lagi". Takrifan kerja merurut [6] merupakan 1. usaha (kegiatan, urusan) yg bertujuan utk menghasilkan (menyelesaikan, menyediakan, dsb) sesuatu: beberapa minggu lagi selesailah membesarkan jalan itu; banyak lagi yg perlu dibuat utk menyambut ulang tahun kemerdekaan;. Selain itu, jika mengambil pengertian [25] tadi iaitu contoh-contoh pasangan yang menurut beliau mempunyai konotasi yang berbeza tetapi denotasi yang sama seperti bilik air/jamban, pengawal keselamatan/jaga, warga emas/warga pencen, dan ibu tunggal/janda, kajian ini mendapati kata kerja/melacur juga bermakna yang sama namun kerja jika bukan dalam konteks pelacuran, tetapi dalam konteks kehidupan bermoral, membawa makna sesuatu perkara yang dilakukan untuk mendapat upah yang halal, sementara melacur pula jelas mempunyai makna yang negatif dan pelakunya mempunyai pekerjaan maksiat. Oleh sebab itu, dalam konteks pelacuran pula, makna konotatif kerja ialah melacur. Golongan pelacur menganggap pelacuran sebagai sebuah kerja untuk mendapatkan duit.

\section{Romen}

Contoh ayat

a. "Abang dah makan ke belum? Macam tak kuat je time beromen".

b. "Abang nak beromen dengan sayang sampai pagi esok".

Romen merupakan kata pinjaman bahasa Inggeris yang merupakan 'romance'. Romen bermaksud menunjukkan perasaan cinta secara non-verbal. Denotatifnya leksikal ini menurut [6], (romén) merujuk kepada asmara; beromen berasmara, bercumbu-cumbuan. Sebagai contohnya, pasangan yang sedang hangat bercinta akan memanggil cium, peluk, dating dan yang seumpamanya sebagai romen. Manakala, golongan pelacur menggunakan perkataan romen tersebut sebagai kata lain untuk melakukan lebih daripada peluk dan cium iaitu melakukan hubungan maksiat berkenaan. Dalam masyarakat Melayu Sarawak pula, kata "romen" ini juga mempunyai makna yang buruk dan negatif iaitu bagi pasangan kekasih yang belum berkahwin, berjumpa secara rahsia (dating) di tempat-tempat yang sunyi untuk berasmara.

\section{Servis}

Contoh ayat :

a. "Bos mau apa macam servis?".

b. "Nak servis terbaik. Bayar pon mesti terbaik."

Servis merupakan satu perkataan yang digunakan untuk menyampaikan maksud memperbaiki sesuatu benda ataupun barang, lazimnya digunakan di pusat-pusat servis kereta, barangan elektrik dan bayaran terhadap sesuatu perkhidmatan. Berdasarkan [11] servis merupakan 1 pukulan pertama atau giliran pemain memukul bola kpd pihak lawan (dlm permainan badminton, tenis dsb). 2 kerja-kerja menyenggara, membaiki kenderaan, jentera dsb. Tetapi, servis dalam konteks pelacuran ialah pakej yang disyorkan kepada pelanggan yang melanggan pelacur. Servis di sini telah diimprovisikan oleh golongan pelacur sebagai makna konotatif, yang bermakna dalam menawarkan perkhidmatan pelacuran, terdapat pelbagai kategori langganan yang disediakan; seperti pakej pelancongan, pakej seminar dan sebagainyadengan makna yang konotatif. Kajian mendapati, khidmat pelacuran juga ada kelas-kelas tertentu, misalnya dalam [15], terdapat beberapa kelas sosial pelacur; pelacuran kelas tinggi, pelacuran kelas elit, dan pelacuran kelas bawah. Cuma, kajian ini menambah selain kelas pelacur berkenaan, terdapat juga "pakej-pekej" tertentu dalam penawaran perkhidmatan pelacuran ini. 


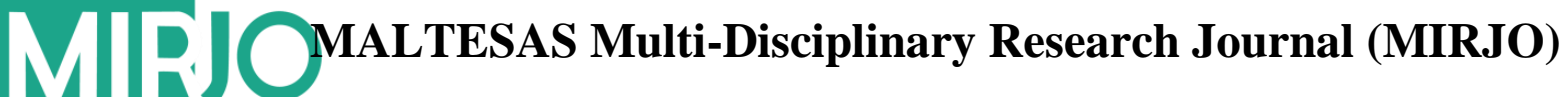

www.mirjo.maltesas.my

\section{Gundik}

Contoh ayat :

"Gundik tu baru sampai semalam ma".

Umumnya, Gundik bermaksud perempuan simpanan. Takrifan leksikal gundik juga dirujuk dalam [6] sebagai 1. isteri yg bukan gahara, isteri tidak rasmi; 2. bini gelap; -candik berbagai-bagai gundik; bergundik mempunyai gundik; bergundikkan mempunyai (seseorang) sbg gundik; mempergundikkan menjadikan gundik; pergundikan perihal bergundik: kongres wanita diadakan utk menentang . Tetapi, dalam kalangan pelacur, menurut informan, gundik bermaksud pelacur yang baharu dan yang tidak pernah melayan ramai pelanggan. Kebanyakan pelanggan lebih suka mencari gundik kerana golongan ini lebih memberikan kepuasan kerana mereka masih baharu. Pemberian makna gundik tersebut sudah semestinya bercanggah dengan makna denotasi yang telah ditakrifkan dalam [6] dan telah membawa makna konotasi bagi leksikal tersebut. Sama juga, seperti kajian [15] yang mengemukakan beberapa kelas sosial pelacur; misalnya pelacuran kelas tinggi, pelacuran kelas elit, dan pelacuran kelas bawah.Maka, daripada kajian tersebut, pelacur kategori "gundik" ini merupakan satu lagi kategori kelas pelacur. Daripada kajian ini dan kajian [15] itu, ternyata terdapat empat kelas sosial pelacur yang boleh disusun semula mengikut kategori, iaitu pelacuran kelas tinggi, pelacuran kelas elit, pelacur gundik dan pelacuran kelas bawah. Dalam kajian ini, pelacur gundik menduduki tempat ketiga dalam empat kelas berkenaan.

\section{Keyword}

Contoh ayat :

"Sini keyword dia cam mana?"

Perkataan 'keyword' dalam bahasa Inggeris bermaksud kata kunci. Berdasarkan takrifan leksikal keyword oleh [5] adalah " a word that you type into a computer so that the computer will find information that contains that word: it a computer concepts". Perkataan kata kunci ini dalam dunia ledakan ilmu pengetahuan sekarang sering digunakan untuk mengingati formula-formula penting dalam pelajaran mahupun kajian. Tetapi, menurut informan, golongan pelacur menggunakan perkataan keyword ini sebagai satu istilah untuk menanyakan harga dan servisservis yang disediakan oleh seseorang pelacur dan telah membawa makna yang konotatif. Sebagai contoh, ujaran "Sini keyword dia cam mana?" mempunyai makna tersirat yang bererti bayaran/caj/harga/kos yang dikenakan oleh pelacur ke atas pelanggan mereka yang jelas sekali telah melanggar makna denotatif yang telah ditakrifkan dalam kamus.

\section{Mangli}

Contoh ayat :

"Itu mangli hah selalu datang sini.".

Mangli bermaksud biasa atau lebih tepat sekali makna denotatif bagi leksikal mangli berdasarkan [6] adalah $K d$ kalis, kebiasaan. Berdasarkan konteks ayat yang digunakan di atas, pelacur bertanya kepada pelanggannya tentang cara layanan yang diingini oleh pelanggan. Menurut informan, pelanggan yang sudah biasa melanggan pelacur, akan bersahaja menjawab dengan perkataan mangli dan perkataan tersebut difahami oleh pelacur bahawa pelanggan mahukan cara layanan yang biasa dalam hubungan tersebut. Leksikal mangli merujuk kepada pelanggan yang sering mendapat perkhidmatan pelacuran di tempat tersebut. Perkara ini juga boleh dikaitkan dengan leksikal "servis" di atas tadi (rujuk data ke-4). Sekali lagi dapat dibuktikan bahawa meskipun sesuatu kata dalam domain pelacur ini mempunyai makna yang kompleks tetapi berbantukan pendekatan semantik, yang secara mudahnya dalam kajian ini melihat makna tersirat di sebalik sesuatu yang tersurat, kita akan dapat mencari makna tersirat yang dihajati. Perkara ini dikuatkan lagi dengan pandangan [26], yang mengatakan bahawa sesuatu objek kata yang dipilih dalam sesuatu ujaran dapat membantu mencari jawapan kepada sesuatu persoalan "mengapa". Hal ini akan mengukuhkan lagi gambaran makna yang hendak disampaikan oleh golongan pelacur yang membawa makna yang konotatif. 


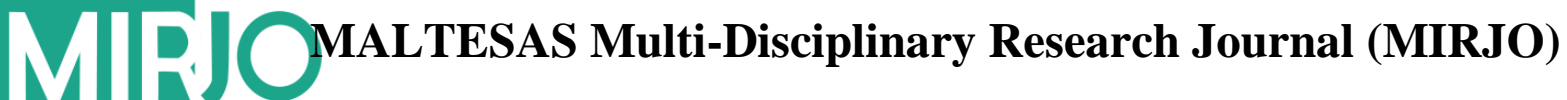

www.mirjo.maltesas.my

\section{Tabik}

Contoh ayat :

“Tabik tu yang selalu langgan sini je tiap minggu.".

Manakala leksikal slanga dalam domain pelacur yang seterusnya ialah tabik yang membawa maksud hormat kepada pelanggan yang selalu datang bagi mendapatkan khidmat seks. Menurut [6] leksikal tabik merupakan 1. ucap selamat, salam, selamat (pagi, petang, malam): maka aku memberi demikian bunyinya, "selamat pagi, tuan"; 2. perbuatan menghormati (dgn cara mengangkat tangan dll), hormat, takzim: jalannya keras, tangannya berpintal membuat ; 3. = tabik-tabik minta maaf (ketika melakukan sesuatu), minta izin: jika kita lalu di belakang orang yg sedang duduk, mahulah kita meminta hendak berbuat demikian; kirim sampaikan salam; minta a) minta maaf (ketika masuk ke tempat keramat dll); b) memberi salam (ketika bermohon diri); bersitabik Mn mengalu-alukan tetamu dgn memberi hormat; bertabik hormat-menghormati: dlm percampuran itu lelaki perempuan tidak lagi; menabik 1. memberi salam; 2. memberi hormat (dlm perbarisan dll), mengangkat tabik: kemudian kuangkat tangan $\sim$ kpd mereka. Kajian ini mendapati bahawa leksikal tabik tersebut telah membawa makna yang konotatif kerana ia membawa istilah kepada pelanggan yang kerap melanggan golongan pelacur di kawasan Bukit Bintang, Kuala Lumpur. Contoh ujaran, "Tabik tu yang selalu langgan sini je tiap minggu." telah membawa kepada percanggahan makna denotatif bagi leksikal tersebut. Penggunaan leksikal ini digunakan bertujuan untuk merujuk kepada pelanggan yang sering melanggan mereka secara umum dan tidak khusus kerana ingin merahsiakan identiti dan nama pelanggannya supaya tidak diketahui orang. Dalam pada itu, leksikal ini turut digunakan dalam bahasa harian untuk kita menunjukkan hormat kepada orang yang lebih tinggi dalam hierarki seperti dalam sektor kerajaan. Walau bagaimanapun, dalam slanga pelacur perkataan ini digunakan juga dan kajian mendapati tidak ada makna tersirat di sini.

\section{Sales}

Contoh ayat :

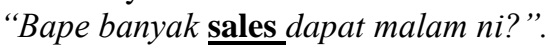

Leksikal sales ini merupakan leksikal asal bahasa Inggeris yang telah diguna pakai dalam slanga pelacur ini. Menurut [27], leksikal sales merupakan kata nama (noun) yang membawa makna "1 mass noun: The exchange of a commodity for money; the action of selling something. "we withdrew it from sale" count noun: "the sale has fallen through". Perkataan sales secara mudahnya membawa maksud keuntungan. Maksud tersurat daripada perkataan sales ialah jualan. Penggunaan istilah sales dalam slanga pelacur juga dalam konteks jualan, tetapi makna tersiratnya atau makna konotatif lebih kepada keuntungan kerana mereka memberikan perkhidmatan secara langsung kepada pelanggan, dan mereka dibayar. Kajian ini mendapati, pelacur mendapat keuntungan lumayan dalam perniagaan maksiat ini.

\section{Nok}

Contoh ayat :

"Nok? Sape yang layan ko tadi tu?".

Seterusnya, dalam slanga pelacur, mereka menggunakan istilah nok bagi menggantikan nama panggilan kepada seseorang pelacur yang mereka kenali. Perkataan ini lebih mesra dan sempoi apabila digunakan untuk memanggil pelacur yang lain. Kajian ini mendapati bahawa leksikal "nok" dalam slanga pelacur ini juga berfungsi seperti kata ganti nama diri orang ke dua iaitu seperti awak/engkau/anda, dan berfungsi juga sebagai kata santun bagi golongan pelacur dalam kumpulan mereka. Walau bagaimanapun, dalam kata dialek sebuah negeri di Semenanjung kata "nok" ini merupakan singkatan bagi kata "nonok" yang bermaksud alat sulit wanita, yang jika dituturkan secara langsung bersifat lucah, yang jelas sekali membawa makna yang konotasi. Manakala di negeri Sarawak pula, sekarang ini terdapat daerah Asajaya yang telah lama menggantikan nama lama daerah itu iaitu daerah Nonok kerana kata "nonok" ini yang berkonotasi buruk di Semenanjung Malaysia tadi. Maka ketika itu, kerajaan negeri 


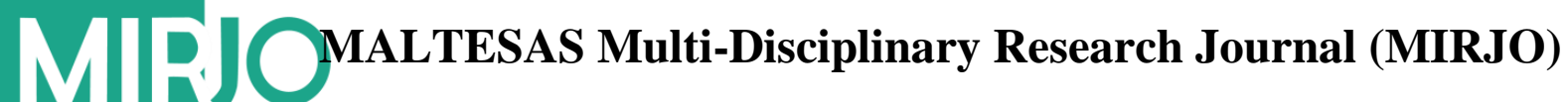

www.mirjo.maltesas.my

Sarawak mengambil jalan menukar nama daerah Nonok kepada daerah Asajaya hinggalah ke hari ini. Oleh itu, dalam slanga pelacur berlainan pula maknanya seperti yang dijelaskan di atas.

\section{Pacat}
a. "Pacat abang boleh tahan ya!"
b. "Pacat abang dah kembang tu. hehe".

Berdasarkan takrifan [11], leksikal pacat merupakan nama sj binatang melata spt lintah tetapi lebih kecil dan gemar menghisap darah, Haemadipsa zeylanica. Dapatan dalam kajian ini mendapati bahawa leksikal pacat telah merujuk kepada makna konotasi bagi alat sulit lelaki dalam slanga pelacur. Kajian lepas juga ada menyentuh mengenai makna konotasi bagi merujuk kepada alat sulit lelaki seperti [1] mengenai slanga yang berkaitan dengan seks iaitu kata $A$ gun di mana makna konseptualnya adalah merujuk pistol jika diterjemahkan secara harfiah namun, implisitnya kata tersebut merujuk kepada alat sulit lelaki seperti mana yang terdapat dalam penulisan novel di negara Nigeria. Manakala kajian Mohammad Shahrul Nizam Abd Wahid [19] dalam Muhammad Zaid Daud, Mohammad Shahrul Nizam Abd Wahid \& Remmy Gedat [20] pula menyatakan bahawa penggunaan eufemisme dalam bahasa Iban yang menggunakan perkataan Palat nuan/dik digantikan dengan leksikal eufemisme loloi bagi merujuk kepada alat sulit lelaki untuk didengari lebih sopan apabila diujarkan. Pacat dalam konteks pelacuran bermaksud alat sulit lelaki manakala dalam bahasa Melayu standard, pacat bermaksud haiwan yang menghisap darah manusia/haiwan. Dengan itu, dalam slanga domain pelacuran ini, leksikal pacat membawa maksud yang tersirat iaitu berkaitan dengan alat sulit lelaki. Melihat kepada semantik konotatifnya, kita melihat kepada keadaan pacat yang boleh mengembang jika menghisap darah dengan banyak. Samalah juga dengan alat kemaluan lelaki, jika terangsang dan telah mencapai tahap ereksi ia akan berkembang. Dengan itu, kegunaan perkataan pacat dalam slanga pelacur ini amat tepat untuk menggambarkan alat sulit lelaki.

\section{Panjat Hotel}

Contoh ayat :
a. "kalau abang nak, abang kena panjat hotel dululah".
b. "dah panjat hotel macam-macamlah bendalah boleh kita buat".

Leksikal denotatif bagi slanga ini adalah panjat yang membawa maksud memanjat 1 menaiki pokok dll dgn bertumpu kaki serta berpaut pd benda yg dinaiki: pokok; tangga. 2 menjadi bertambah tinggi (bkn jalan dll); menaik; mendaki: jalan yg . 3 naik ke atas (bkn tumbuh-tumbuhan) dgn melilit atau dgn berkait pd sokong. memanjati memanjat pd (bkn tumbuh-tumbuhan dsb): Pokok kacang panjang pancang. memanjatkan 1 menaikkan sesuatu pd; membuat supaya memanjat. 2 membaca doa memohon kpd Tuhan: doa agar anak-anaknya berjaya dlm hidup. panjatan 1 tempat memanjat. 2 pergerakan badan ketika memanjat. pemanjat orang yg memanjat. [11]. Makna konotatif merujuk kepada makna lain yang ditambahkan pada makna denotatif, yang ada hubungannya dengan nilai rasa orang yang menggunakan kata itu dan bergantung pada situasi [14]. Berdasarkan slanga tersebut maksud panjat hotel adalah ajakan untuk masuk ke hotel terlebih dahulu sebelum membuat rundingan dan tawarmenawar untuk mendapatkan perkhidmatan pelacur ini. Kajian ini mengemukakan makna di sebalik tujuan mengajak masuk ke hotel ini, sebagai tanda bersetuju untuk melanggan pelacur tersebut. Pada masa yang sama, dapat mengelakkan pihak berkuasa daripada menghidu pekerjaan mereka di bawah hotel itu. Sekiranya kita hanya dapat membayangkan perbuatan, panjat hotel mungkin sekadar memanjat bangunan hotel bagi pelbagai tujuan seperti membersihkan tangki air hotel, membuat penyambungan wayar di bahagian atas hotel dan sebagainya (merujuk kepada kerja-kerja yang bersifat pemasangan, pembaik pulih keadaan di hotel) namun, berbeza pula dengan slanga yang digunakan oleh golongan pelacur ini kerana membawa maksud masuk ke dalam hotel bagi tujuan mendapatkan perkhidmatan mereka. Dalam kajian bidang semantik menurut [23][24] yang telah mengkaji pembayang dan maksud dalam peribahasa, menegaskan bahawa sememangnya pembayang dan maksud berkait rapat dan bukannya dicipta di luar konteks [23][24]. Berdasarkan pandangan ini juga, kajian ini mengemukakan 


\section{VMALTESAS Multi-Disciplinary Research Journal (MIRJO)

www.mirjo.maltesas.my

bagaimana nilai perkataan panjat hotel dipentingkan lalu dikaitkan dengan pemikiran dalam slanga pelacuran ini kerana perkataan tersebut terdapat makna implisit yang digunakan pelacur dengan pelanggan mereka. Ujaran kata dengan mengaitkannya dengan pemikiran mereka dan santun bahasa mereka yang mempunyai makna tersirat dapat membantu kita dalam mentafsir ayat tersebut.

\section{Sekerat Jalan}

Contoh ayat :

"Kalau polis datang, sekerat jalan ye sayang.".

Makna denotatif bagi slanga ini terdapat dua iaitu sekerat dan jalan. Bagi leksikal sekerat membawa maksud sebahagian drpd sesuatu yg telah dipotong; penggal; potong: se batang ubi kayu; pantun empat . berkerat sudah atau telah dikerat: Daun-daun pandan yg itu pun dilayur. mengerat memotong; memenggal; memancung (leher): $\sim$ kayu; leher. terkerat terpotong; terpenggal. keratan bahagian drpd sesuatu yg telah dikerat; potongan; penggalan. memanjang keratan yg dibuat secara memanjang (pd sesuatu). rentas (lintang) keratan yg dibuat secara merentas sesuatu. [11]. Manakala makna denotasi bagi leksikal jalan pula, menurut [6], 1 tempat lalu lintas (kenderaan atau manusia) yg dibina drpd batu dan tar, tanah merah dll: ke rumah saya belum bertar lagi. 2 ikhtiar; cara; akal: Ia mencari utk mengambil buah yg tinggi itu. 3 gerakan (kereta, jarum jam dsb): Kereta ini laju nya. 4 perkembangan sesuatu peristiwa (cerita dsb): cerita. bahasa gaya penggunaan bahasa dlm sesebuah cerita (novel, prosa dsb). Jika kedua-dua leksikal ini berasosiasi iaitu sekerat jalan akan bermaksud tidak melakukan sesuatu pekerjaan sehingga selesai. Dalam konteks pelacuran pula mempunyai makna yang berkonotasi kerana, sekerat jalan merupakan amaran kepada pelanggan bahawa mereka tidak akan mendapat layanan yang sepenuhnya sekiranya mereka ingin bertindak luar daripada jangkaan apabila terdapat rondaan polis. Maka mereka terpaksa berhenti untuk melarikan diri atau bersembunyi daripada tangkapan polis. Selain itu, sekerat jalan di sini juga bermakna perkhidmatan yang ditawarkan terpaksa dihentikan jika tidak bertepatan dengan bayaran yang dikenakan. Pelacur berharap agar pelanggan tidak memarahi mereka, maka sebab itu, menurut informan kata "sayang" diselitkan untuk mendapat persetujuan pelanggan. Pada masa yang sama, kajian ini juga mendapati kata sekerat jalan mampu menjadi kata kunci kepada pelanggan sebagai langkah berjaga-jaga untuk meninggalkan hotel sekiranya berlaku serbuan daripada pihak berkuasa.

\section{China Doll}

\section{Contoh ayat :}

"Cuba China Doll bos. Terbaik punya".

Istilah China Doll pula secara amnya membawa maksud tersurat iaitu patung Cina ataupun patung dari negara China. Jika dirujuk kepada makna denotasi bagi dua leksikal ini iaitu, China - nama negara (benua); Tiongkok. [11] dan Doll membawa maksud patung jika diterjemahkan secara harfiah daripada bahasa Inggeris ke bahasa Melayu. Doll/patung merujuk kepada 1. sesuatu bentuk manusia (binatang dll) yg dibuat drpd batu (logam, kayu, dll), arca: di atas tugu itu - polis khas akan didirikan; duduk spt $\sim$ duduk tidak bergerak; 2. = anak $\sim$ patung kecil (permainan kanak-kanak), anak-anakan, boneka; 3. ki orang dll yg menjadi lambang sahaja (menjadi permainan orang lain dll): maharaja itu menjadi , dimainkan oleh maharaja yg sudah bersara; mematung (diam, tiada bergerak-gerak) spt patung: gadis itu tetap ; dia di tepi kereta; mematungkan 1. menyebabkan jadi patung, menjadikan patung; 2. memandang (menganggap) sbg patung. [6].

Walau bagaimanapun, slanga China Doll dalam bahasa pelacur lebih merujuk kepada maksud konotasi iaitu pelacur-pelacur yang diimport dari negara China. Kajian ini dikuatkan lagi dengan dapatan kajian kes oleh Fatin Hafizah Mohd. Sahar dan Mahani Ishak [7] mengenai tangkapan perempuan warga negara asing yang disyaki 


\section{VILTESAS Multi-Disciplinary Research Journal (MIRJO)

\section{www.mirjo.maltesas.my}

pelacur bagi tahun 2012-2015 daripada bulan Januari sehingga Julai, mendapati jumlah tangkapan pelacur meningkat setiap tahun dengan pelacur dari negara China mempunyai tangkapan yang paling tinggi jika dibandingkan dengan negara-negara lain (rujuk JADUAL 2).

JADUAL 2. Tangkapan Perempuan Warga Negara Asing Yang Disyaki Pelacur Bagi Tahun 2012 - 2015 (Januari - Julai)

\begin{tabular}{cccccc}
\hline Bil. & NEGARA & $\mathbf{2 0 1 2}$ & $\mathbf{2 0 1 3}$ & $\mathbf{2 0 1 4}$ & $\mathbf{2 0 1 5}$ \\
\hline $\mathbf{1 .}$ & China & 5165 & 4220 & 4523 & 1706 \\
\hline $\mathbf{2 .}$ & Indonesia & 1418 & 1258 & 1450 & 648 \\
\hline $\mathbf{3 .}$ & Thailand & 2009 & 3158 & 4635 & 795 \\
\hline $\mathbf{4 .}$ & Vietnam & 3456 & 4862 & 7561 & 4756 \\
\hline $\mathbf{5 .}$ & Filipina & 845 & 465 & 749 & 271 \\
\hline $\mathbf{6 .}$ & Myanmar & 114 & 130 & 216 & 159 \\
\hline $\mathbf{7 .}$ & India & 139 & 110 & 261 & 159 \\
\hline $\mathbf{8 .}$ & Uzbekistan & 70 & 6 & 58 & 9 \\
\hline $\mathbf{9 .}$ & Laos & 30 & 36 & 110 & 85 \\
\hline $\mathbf{1 0}$ & Kampuchea & 70 & 171 & 210 & 81 \\
\hline & Jumlah & $\mathbf{1 3 3 1 6}$ & $\mathbf{1 4 4 1 6}$ & $\mathbf{1 9 7 7 3}$ & $\mathbf{8 6 4 9}$ \\
\hline
\end{tabular}

(Sumber : Dipetik dan diubahsuaikan daripada Fatin Hafizah Mohd. Sahar dan Mahani Ishak, Pelacuran Jejas Moral Masyarakat. Berita Harian, pp. 12-13, 2016).

Istilah doll juga membawa makna yang konotatif kerana leksikal doll merujuk kepada jantina iaitu perempuan. Oleh itu, kajian ini dapat merumuskan bahawa slanga china doll ini dapat merujuk kepada pelacur perempuan dari negara China.

\section{Monggel-monggel}

“adik-adik kat sini banyak yang monggel-monggel..”

Menurut [6] leksikal mongel (mongél) merujuk kepada 1. kecil molek, cantik; 2. menarik hati (anak); kemongelan kecantikan: menatap dan me-nikmati tubuh Jane Fonda. Leksikal Mongel ataupun mungil secara denotatifnya yang merujuk kepada gadis kecil molek yang berumur belasan tahun seperti 18 dan ke atas dan mempunyai paras rupa yang cantik dan menarik. Kajian ini mendapati leksikal monggel dalam slanga pelacur ini yang digunakan untuk merujuk pelacur baharu yang masih muda dalam lingkungan umur 18 tahun ke atas dan mempunyai perwatakan yang menarik, membawa makna yang konotatif. Didapati juga bahawa pelacur yang mungil ini menjadi pilihan pelanggan maksiat selain pelacur kelas gundik dan China doll di atas.

\section{Siram/tanam Bunga}

Contoh ayat :

a. "Boleh abang siram bunga untuk adik cantik ni tak?".

Contoh ayat :

b. "Nak tanam bunga dalam tak air abang?".

Sebelum perbincangan data terakhir ini kepada makna yang konotatif pengkaji akan menghuraikan terlebih dahulu makna denotatif bagi leksikal siram, taman serta bunga. Berikut merupakan makna denotasi bagi ketiga-tiga leksikal tersebut.

1. siram - bersiram mandi (digunakan utk raja-raja saja): Silakan tuanku berangkat . menyiram 1 mencurahkan air dsb pd sesuatu: bunga. 2 menjirus dgn air (supaya bersih dll). menyirami 1 menyiram berkali-kali; menyiram banyak-banyak. 2 menjadikan sesuatu disiram: Hujan bumi. menyiramkan menyiram dgn (sesuatu); 


\section{MIRJ OMALIESAS Multi-Disipininary Reserech Journal (MIIJJ)

www.mirjo.maltesas.my

mencurahkan; mencucurkan: air mawar pd bunga rampai. persiraman tempat bersiram; permandian. penyiraman perbuatan (hal dsb) menyiram, menyirami atau menyiramkan. penyiram alat utk menyiram [11].

2. tanam - cucuk perihal tanam-menanam (bertani); musim musim menanam padi; bertanam 1. sedang bercucuk tanam, membuat pekerjaan pertanian: kehidupan mereka itu memukat dan padi; 2. sl mengebumikan, menguburkan mayat: di bawah gereja itulah tempat orang Hollanda orang mati; cacar bersuntik; berkotek (berketuk) di luar sangkar, di luar pagar prb sesudah perkara selesai barulah terdengar keterangan atau aduan;. [6].

3. bunga - 1 bahagian tumbuh-tumbuhan yg biasanya berwarna-warni dan akan menjadi buah: Jangan dipetik $\sim$ itu. 2 gambar atau lukisan sbg perhiasan pd kain dsb: Kain batik ini cantik sungguh $\sim$ nya. $3=\sim$ wang wang yg diperoleh kerana meminjamkan wang atau kerana memberikan modal; keuntungan drpd modal; faedah: Pinjaman itu telah dikenakan sebanyak lima peratus. 4 ki sesuatu yg dianggap cantik atau menarik:. [11].

Oleh itu, jika leksikal tersebut berasosiasi akan membentuk kepada slanga domain pelacur iaitu siram bunga dengan tanam bunga yang berkonotasi. Berdasarkan contoh ujaran (a). "Boleh abang siram bunga untuk awek cantik ni tak?" merupakan ayat yang diujarkan dengan intonasi rendah dan bermaksud untuk bermanja-manja dan memuji-muji pelacur oleh pelanggan. Sementara contoh ujaran (b). "Nak tanam dalam tak air abang" merupakan jawapan kepada pertanyaan pelanggan tadi. Dalam slanga pelacur, pengkaji mendapati siram bunga atau tanam bermaksud melepaskan air mani ke dalam alat sulit pelacur. Penggunaan istilah ini dianggap lebih manja bagi pelacur semasa mereka melakukan hubungan berkenaan kerana perkataan tersebut tidak kasar sama sekali. Perkataan ini membawa maksud konotasi kerana perkataan tersebut tidak membawa maksud asal perkataan bagi menyiram/siram bunga dan tanam, tetapi membawa maksud yang berkenaan di atas. Perkara ini dikuatkan lagi dengan pendefinisian slanga oleh [21] iaitu suatu mainan bahasa kerana penutur bebas menggunakan bahasa tanpa memikirkan kegramatisan sesuatu perkataan atau ayat tersebut sehingga ia dapat membentuk sesuatu makna yang baharu ataupun berlainan daripada makna asalnya.

\section{KESIMPULAN}

Makna konotatif yang terdapat dalam bidang semantik telah dapat diaplikasikan untuk merungkai setiap makna slanga dalam domain pelacur ini. Setiap slanga yang diungkapkan oleh golongan pelacur ini telah menjadi kata rahsia dan kebiasaan bagi golongan ini, iaitu sebagai komunikasi antara pelacur dan pelanggannya. Kata-kata tidak langsung ini sememangnya digunakan untuk mencapai makna kefahaman bersama antara pengujar dan penutur, terutama sekali mereka yang berkongsi konteks yang sama. Boleh juga dikatakan, kata-kata berahsia ini atau dalam konteks kajian ini slanga pelacur begitu rapat dengan pemikiran serta kehidupan masyarakat mereka. Kajian slanga dalam pertuturan pelacur ini, walaupun berbaur lucah, namun bagi mereka adalah halus, tidak seperti yang didakwa sebelum ini, iaitu slanga tidak boleh dianggap halus. Kajian ini mendapati, bagi mereka itulah bahasa halus mereka yang penuh rahsia. Kajian ini mencadangkan pada masa hadapan, penyelidikan seperti ini dapat memberikan gambaran yang tepat dan menyeluruh kepada sarjana tempatan atau sarjana Barat yang berminat untuk mendalami budaya hidup dan budaya komunikasi masyarakat seperti golongan pelacur ini , yang jarang-jarang atau tiada langsung dibicarakan tentang mereka dalam dunia akademik. Walaupun bahasa mereka berbaur lucah dan kesat, dunia akademi seperti jurnal-jurnal akademik perlu mengetengahkan kajian seperti ini untuk kepentingan akademik dan kerancakkan penyelidikan dunia bahasa.

\section{PENGHARGAAN}

Setinggi-tinggi penghargaan juga diberikan kepada Kharull Haffis Ngairan (47182), Mohammad Shahrul Nizam Abd Wahid (49796), Tangaprabu Murthy (47251) dan Gayathiry Solan (49696) dari Fakulti Bahasa dan Komunikasi, Universiti Malaysia Sarawak kerana telah bersama-sama menjayakan pengutipan data kajian ini. 


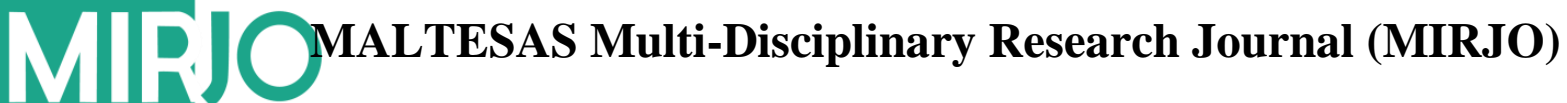

www.mirjo.maltesas.my

\section{RUJUKAN}

[1] Aboh, R. "Slang and Multiple Methods of Interpreting Sex and Sexual Identity in the Nigerian Novel." The African Symposium: An online journal of the African Educational Research Network, vol. 15, no. 1, 2015, pp. 91-97.

[2] Ahmad, Ismail, and Dania Dirani. Orang Macam Kita. Matahari Books Publisher, 2010.

[3] Arua, A. E., and Modupe M. A. "The Creation of Students' Academic Slang Expressions in the University of Botswana." Linguistik Online, vol. 9, no. 4, 2009, pp. 15-28.

[4] Bloomfield, L. Language. New York: Rinehart \& Winston, INC, 1933.

[5] Cambridge International Dictionary of English. Cambridge UP, 2002.

[6] Dewan Bahasa dan Pustaka. Kamus Dewan Edisi Keempat. Dewan Bahasa \& Pustaka, 2010.

[7] Fatin Hafizah, Mohd. Sahar, and Mahani Ishak. "Pelacuran Jejas Moral Masyarakat." Berita Harian, [Kuala Lumpur], 19 Jan. 2016, pp. 12-13.

[8] Gan, K. L. "Strategi Penukaran Kod di Kalangan Guru-Guru Cina Berpendidikan Cina dan Bukan Berpendidikan Cina: Satu Kajian Kes." 2000. Universiti Malaya, Kuala Lumpur, Malaysia, MA thesis.

[9] Gay, L R, and Airasian P. W. Student Guide for Educational Research: Competencies for Analysis and Application, Third Edition. Merrill Pub. Co, 2003.

[10] Kamus Elektronik Dewan Eja Pro. Petaling Jaya. The Name Technology Sdn.Bhd, 2009.

[11] Kamus Pelajar Bahasa Melayu Dewan. 2nd ed., Kuala Lumpur: Dewan Bahasa dan Pustaka, 2016.

[12] Katamba, F. English words. New York: Routledge, 1994.

[13] Kheren Kezia Adolof. "Slang dalam Lagu Black Eyed Peas." 2014. Universitas Sam Ratulangi, Indonesia, MA thesis.

[14] "Makna Denotatif Dan Makna Konotatif." RujukNota, 21 Dec. 2011, rujuknota.blogspot.my/2011/12/maknadenotatif-dan-makna-konotatif.html. Accessed 1 Oct. 2017.

[15] Mary Fatimah, Subet. "Sajak "Pelacur Tua" Analisis Teori Relevans." Jurnal Bahasa, vol. 15, no. 1, 2015, pp. 113-142.

[16] Mary Fatimah, Subet, and Muhammad Zaid Daud. "“Giler" Atau "Gile": Slanga Kata Penguat." Jurnal Bahasa, vol. 16, no. 2, 2016, pp. 293-306, jurnalbahasa.dbp.my/wordpress/wp- content/uploads/2016/12/6Giler.pdf.

[17] "Semantik dan Makna Konotasi dalam Slanga Pelacur." 2017, The International Conference on Language Studies (iCLS) 2017. Kuching (Riverside Majestic Hotel).

[18] Mhd. Amin, Arshad. Bahasa Slanga: Pembentukan dan Ciri-Cirinya dalam Monograf Bahasa, Sastera, dan Budaya Melayu. Serdang, Selangor: UPM, 2000.

[19] Mohammad Shahrul Nizam, Abd Wahid. "Eufemisme dalam Bahasa Iban: Satu Kajian Kes di Kampung Lebor, Serian, Sarawak." 2017. Universiti Malaysia Sarawak, Malaysia, Unpublished final year project.

[20] Muhammad Zaid, Daud, et al. "Eufemisme dalam Bahasa Iban: Satu Kajian Kes di Kampung Lebor, Serian, Sarawak." Borneo Research Journal, vol. 11, no. 1, 2017, ajap.um.edu.my/index.php/ BRJ/article/view/102 $04 / 7239$.

[21] Muhammad Zaid, Daud. "Slanga Kedai Kopi: Satu Analisis Semantik Inkuisitif." 2017. Universiti Malaysia Sarawak, Malaysia, Unpublished final year project.

[22] Nadia, Suboh. "Aspek Bahasa Melayu dalam Penulisan Blog Berdasarkan Perisisan Pengukuran NEMD Versi 2.0." 2013. Universiti Putra Malaysia, Serdang, Malaysia, MA thesis.

[23] Nor Hashimah, Jalaluddin. Semantik Dan Akal Budi Melayu. Penerbit UKM, 2014.

[24] Pemugaran Penyelidikan Untuk Pemerkasaan Bahasa. 2014. eseminar.dbp.gov.my/ceramahnj/kertas_kerja _norhashimah_jalaluddin.pdf-. Accessed 5 Feb. 2016.

[25] Norsimah, Mat Awal. "Semantik." Pengenalan Linguistik: Teoretis dan Aplikasi, Dewan Bahasa dan Pustaka, 2014.

[26] Nur Afiqah, Wan Mansor, and Nor Hashimah Jalaluddin. "Deria Rasa Dalam Kiasan Melayu: Analisis Semantik Inkuisitif." Journal Pertanika Mahawangsa, vol. 2, no. 1, 2015, pp. 1-16.

[27] Oxford, Dictionaries. Colour Oxford Dictionary \& Thesaurus. Oxford Univ P, 2011.

[28] Setiawan, Nugroho. "Pembentukan Kosakata Slang dalam Komunitas JKBOSS Pada Akun Twitter @ JakartaKeras." 2015. Universitas Negeri Yogyakarta, Indonesia, MA thesis. 


\section{VIALTESAS Multi-Disciplinary Research Journal (MIRJO)

www.mirjo.maltesas.my

[29] Shahraki, Sara H., and Abbass E. Rasekh. "Check This One out: Analyzing Slang Usage among Iranian Male and Female Teenagers." English Language Teaching, vol. 4, no. 2, 2011, p. 198.

[30] Tay, M. G. "Analisis Linguistik Terhadap Penggunaan Bahasa SMS dalam Kalangan Guru Pelatih." Jurnal Penyelidikan IPG Kampus Batu Lintang, vol. 10, no. 1, 2010, pp. 1-26.

[31] Yusoff, Marohaini. Penyelidikan Kualitatif Penggalaman Kerja Lapangan Kajian. Penerbitan Universiti Malaya, 2001.

[32]Zhou, Yanchun, and Yanhong Fan. "A Sociolinguistic Study of American Slang." Theory and Practice in Language Studies, vol. 3, no. 12, 2013.

[33]Zuraidah, Mohd Sulaiman, et al. "Slanga Remaja Melayu Dan Cina: Analisis Awal Berdasarkan Teori Relevan." 2012, International Conference On Arts, Social Sciences, And Technology (ICAST2012). 